Marcus Matthias Keupp, Maximilian Palmié, and Oliver Gassmann (2011)

\title{
Achieving Subsidiary Integration in International Innovation by Managerial “Tools”
}

The final version of this manuscript is published in Management International Review, 51(2): 213-239.

The final publication is available at www.springerlink.com:

http://link.springer.com/content/pdf/10.1007\%2Fs11575-011-0072-5

DOI: $10.1007 / s 11575-011-0072-5$

http://dx.doi.org/10.1007/s11575-011-0072-5

Please note that differences between this manuscript and the final publication may exist. In case of questions, please contact the corresponding author as indicated below. 


\section{Achieving Subsidiary Integration in International Innovation by Managerial “Tools”}

Marcus Matthias Keupp • Maximilian Palmié • Oliver Gassmann

\section{Abstract}

- Our study articulates and empirically tests a theory of how the parent firm of a multinational corporation (MNC) can achieve global integration of subsidiaries into the MNC's intrafirm network by using managerial "tools" to manipulate the MNC's formal organizational architecture.

- Taking a subsidiary's performance as an observable criterion to measure the success of its integration into the global intra-firm network, the model is tested on a unique dataset of 287 international R\&D subsidiaries.

- Our findings suggest that the parent firm can actively improve a subsidiary's performance and hence its integration by encouraging knowledge asset transfer, by granting the subsidiary a mandate for undertaking activities on behalf of the corporation as a whole, and by providing it with more operational autonomy.

- These findings open up a deep perspective of how subsidiary integration can be achieved by appropriate managerial "tools" in the context of international innovation. We discuss the implications of these results for the literature and for managers.

Keywords: Subsidiary Integration - Organizational Architecture • Managerial Tools • Strategic Autonomy • Operational Autonomy • International Innovation

\section{Authors}

Ass. Prof. M. M. Keupp • PhD Cand. M. Palmié $(\bowtie) \bullet$ Prof. O. Gassmann Institute of Technology Management, University of St. Gallen, St. Gallen, Switzerland (e-mail: maximilian.palmie@unisg.ch) 


\section{Introduction}

A major reason why multinational corporations (MNCs) exist is their ability to globally leverage dispersed subsidiary-specific advantages and to generate new knowledge through a global synthesis of dispersed knowledge (Almeida and Phene 2004; Andersson et al. 2002; Buckley and Carter 1996; Davis and Meyer 2004; Rugman and Verbeke 2001). These abilities constitute a major source of competitive advantage for MNCs (Andersson et al. 2002; Ghoshal 1986; Ghoshal and Nohria 1989; Rosenzweig and Singh 1991; Yamin and Sinkovics 2009). Over the past two decades, many MNCs have dispersed their knowledge development processes internationally and started to perform an increasing share of their research and development (R\&D) activities abroad, attempting to integrate subsidiaries into a global innovation network (Cantwell 1989; Dunning 1994; Granstrand et al. 1992; Hakanson 1995; Serapio and Dalton 1999).

"Integration of subsidiaries" designates the continuous leveraging of each subsidiary’s knowledge base within the MNC (Mudambi 2002, p. 4). Typically, by such integration, MNCs strive to utilize information and other knowledge assets developed by diverse subsidiaries, to coordinate and integrate activities across geographically dispersed subsidiaries, and to centralize decision-making authority while maintaining local responsiveness (Yeniyurt et al. 2005).

While the beneficial effects of global integration have been highlighted in the literature, little attention has been devoted to the question of how (i.e., by which means) it can actually be achieved (Björkman et al. 2004; Foss and Pedersen 2002; Persaud 2005). The study of categorical subsidiary types and roles (e.g., Birkinshaw and Morrison 1995; Frost et al. 2002; Nobel and Birkinshaw 1998) contributes little to our understanding of how integration can be achieved because there might be 
considerable variation across subsidiaries that are assigned to the same category, and the boundaries between categories may not be clear-cut (Asmussen et al. 2009; Birkinshaw and Hood 1997; Nobel and Birkinshaw 1998). Contributions that focus on antecedents of knowledge transfers by subsidiaries (e.g., Gupta and Govindarajan 2000; Hakanson and Nobel 2001; Hansen 1999; Szulanski 1996; Zander and Kogut 1995) are limited in their ability to analyze whether or not these knowledge transfers ultimately lead to global integration of subsidiaries, since knowledge must be put to appropriate use after transfer to generate value (Ambos and Ambos 2009; Haas and Hansen 2005; Kotabe and Mudambi 2004; Yamin and Otto 2004).

With very few knowledge-based empirical exemptions (Björkman et al., 2004; Foss and Pedersen, 2002) and the exploratory study of Persaud (2005), a persistent knowledge gap exists regarding how (i.e., by which means) integration can be achieved (Ambos and Ambos 2009; Bouquet and Birkinshaw 2008; Foss and Pedersen 2004; Luo 2002; Wu et al. 2007).

The purpose of this paper is to help close this gap by asking: "How, if at all, do managerial "tools” enhance subsidiary performance and thus contribute to global integration?” By “(managerial) tools”, we understand those means that managers use to create a promising structural context for conducting business (Doz and Prahalad 1984; Melin 1992). We focus on "tools" by which the parent firm can manipulate the MNC's formal organizational architecture. Thus, the paper contributes to the literature in multiple ways.

First, since we study "tools" on the organizational level of analysis, we can add an organizational-level complement to the individual-level focus of prior studies that have focused on behavioral and social control mechanisms as antecedents of integration (e.g., Björkman et al. 2004; Persaud 2005). Second, using subsidiary 
performance as an indicator for successful integration, we simultaneously study antecedents of subsidiary performance for which empirical evidence is rare (Monteiro et al. 2008). Third, distinguishing between strategic and operational autonomy as antecedents of integration allows us to address the frequently highlighted conflict between the subsidiary's freedom to create knowledge assets and the coordination that is necessary to globally integrate these (e.g., Birkinshaw et al. 1998; Persaud 2005; Yamin and Otto 2004) and thus to help resolve inconsistent findings on the influence of autonomy (Ambos and Schlegelmilch 2007; Young and Tavares 2004). Fourth, we contribute to resolving the paradox that many MNCs seem to re-centralize or completely localize activities rather than to achieve effective global integration (Benito et al. 2003; Currie and Kerrin 2004; Doz et al. 2006; Fors 1997; Pearce 1990; Rugman 2005) by studying how global integration can be achieved by deploying appropriate managerial “tools”. Finally, these contributions also create beneficial advice for executives (Foss and Pedersen 2002).

From a theoretical framework anchored in the resource-based view of the firm that links subsidiary performance to successful global integration, we develop hypotheses on three specific "tools": inter-subsidiary knowledge asset transfer, subsidiary mandate, and subsidiary autonomy. We use a unique sample of $287 \mathrm{R} \& \mathrm{D}$ subsidiaries to test these, finding strong support for our claims. We finally discuss implications for theory, managerial practice, and future research. 


\section{Theoretical Framework and Hypotheses}

The successful integration of a subsidiary into the MNC network is more likely when the parent firm's integration attempts are actively supported by the subsidiary (Luo 2005; Szulanski 2003). Subsidiaries, however, tend to be primarily interested in their own ends and only secondarily in those of the MNC or of the parent firm (Mudambi and Navarra 2004; Nohria and Ghoshal 1994). We therefore expect that subsidiaries are more willing to attend to headquarters' interests if they believe that headquarters' and their own interests are compatible (Eisenhardt 1989, p. 62). Among the primary goals of a subsidiary is its interest to increase its own financial performance (Mudambi and Navarra 2004). Increased performance is likely to lead to significant advantages for the subsidiary and its staff, such as a significant reduction of the possibility that the parent firm will divest the subsidiary, greater influence on strategic decisions of the parent firm, or increasing bonus payments for subsidiary managers (Andersson et al. 2001; Björkman et al. 2004; Hite et al. 1987). A subsidiary's willingness to contribute to global integration is therefore likely to be associated with its expected improvements of its own financial performance.

The resource-based view of the firm (RBV) suggests that superior financial performance is linked to superior resource endowments, superior resource utilization, or both (Amit and Schoemaker 1993; Barney 1991; Crook et al. 2008; Teece et al. 1997; Wernerfelt 1984). It can provide a strong conceptual foundation to analyze the effects of a global integration strategy on MNC performance (Yeniyurt et al. 2005; Zou and Cavusgil 2002). To exploit and improve an organization's resource base are central motives of an integration strategy, since the resulting superior resource endowments are likely to lead to superior performance in the future (Yeniyurt et al. 2005, p. 3). 
Substantial improvements in the resource endowments or resource utilization of the overall MNC network are likely to be associated with substantial improvements of the resource endowments or resource utilization of the involved subunits. Therefore, the parent firm should be interested in improving the subsidiary's resource base or utilization of resources. For the same reason, subsidiary performance should be positively associated with the extent to which a subsidiary is integrated into the MNC's global intra-firm network (Tsai 2001). Therefore, the parent firm has an incentive to manipulate its internal organizational structure such that this manipulation is likely to augment the subsidiary's resource base or resource utilization. Such manipulation can affect the MNC's formal structure, its informal structure, or both. In this paper, we focus exclusively on "tools" that manipulate the firm's formal organizational structure, since managers can make discrete choices to shape their firm's formal structure, whereas the informal organization is typically rather difficult to shape directly (Nickerson and Zenger 2002). While informal architecture merely emerges, formal architecture is explicitly mandated (Gulati et al. 2009, emphasis added). Therefore, manipulating formal structure will likely be key if managers want to change their organization (Ethiraj and Levinthal 2004). We concentrate on three specific formal "tools" for which there is consensus in the literature regarding their importance and relevance: inter-subsidiary knowledge asset transfer (cf. Kogut and Zander 1992; Luo 2002; Szulanski 1996; Townsend et al. 2004; Tsai 2002), subsidiary mandates (cf. Birkinshaw 1996; Birkinshaw et al. 1998; Cantwell and Mudambi 2005; Feinberg 2000; Roth and Morrison 1992), and subsidiary autonomy (cf. Birkinshaw et al. 2005; Gates and Egelhoff 1986; Johnston and Menguc 2007; Nobel and Birkinshaw 1998; Young and Tavares 2004). 
The selection of these three particular "tools" also seems appropriate to ensure that each of the three interwoven aspects of Yeniyurt et al.'s (2005) integration framework is addressed: the encouragement of knowledge asset transfers is especially related to the emergence of a globally shared knowledge base; the granting of a mandate to the global exploitation of an individual unit's strengths (which is the motive behind value-chain coordination); and subsidiary autonomy - especially since we distinguish between strategic and operational autonomy - to balancing central authority and responsiveness to local markets. We now develop specific hypotheses anchored in the RBV that link these "tools" to subsidiary performance by analyzing changes in resource endowments and utilization.

Hypothesis 1: Association between Knowledge Asset Transfer and Subsidiary Performance

Knowledge assets comprise information, know-how, practices, capabilities, technologies, and products (Yang et al. 2008, p. 887, p. 889). Subsidiaries that transfer knowledge assets to other subsidiaries may benefit from this transfer because engaging in knowledge transfer creates reciprocity (Gouldner 1960; Monteiro et al. 2008). Thus, knowledge tends to flow to those units that frequently share their knowledge with the rest of the organization. This is likely to end up creating a subgroup of units within the MNC that are frequently exchanging knowledge among themselves, while those units that rarely act as sources of knowledge transfers are also unlikely to receive knowledge from other units (Monteiro et al. 2008).

Subsidiaries with greater knowledge inflows generate a greater knowledge output (Mudambi and Navarra 2004). The recombination of particularly strong 
competencies from different units may stimulate the further development of these competencies (Kogut and Zander 1992, 2003). Thus, an isolated subsidiary that does not participate in such exchange relationships is likely to perform worse than other subsidiaries (Monteiro et al. 2008; Tsai 2001).

Further, the transfer of knowledge assets to other subsidiaries is also likely to increase the importance of the transferring subsidiary for the MNC group, which should in turn increase its bargaining power and strategic influence within the intrafirm network (Forsgren and Pedersen 2000; Forsgren et al. 2000; Mudambi and Navarra 2004). This greater bargaining power within the MNC gives the focal subsidiary the opportunity to directly appropriate a higher level of the rents that are available within the intra-MNC network (Mudambi and Navarra 2004). Therefore, by encouraging the transfer of knowledge assets between subsidiaries, the parent firm should be able to positively influence the subsidiary’s performance and thus its global integration. Thus,

Hypothesis 1: Subsidiary performance will be positively associated with intersubsidiary knowledge asset transfer.

Hypothesis 2: Association between Mandate Status and Subsidiary Performance

By a subsidiary mandate, the parent firm gives a subsidiary the responsibility to undertake certain activities on behalf of the corporation as a whole, implying international rather than just local responsibility for these activities (Birkinshaw et al. 1998). We argue that such a “mandate status” should increase subsidiary performance. A subsidiary that is granted a mandate has probably already demonstrated either superior competencies in the past or at least an ability to develop such superior 
competencies (Andersson et al. 2002; Forsgren et al. 2000), and by conducting the corresponding activities on a larger scale, it should be able to further develop these competencies (Frost et al. 2002). Superior competencies, in turn, are positively related to superior performance (e.g., Delios and Beamish 1999), so that mandate status and superior performance should be positively associated.

Second, a subsidiary that is granted a mandate can probably increase its investments in competence development because assuming an advanced role in the MNC network - for which a mandate is likely to be a signal - is typically accompanied by additional resource investments made by the parent firm in the subsidiary (Birkinshaw and Hood 1998; Frost et al. 2002). Since greater investments stimulate the development of competencies (e.g., Barney 1991; Dierickx and Cool 1989; Frost et al. 2002), mandate status and superior performance should be positively associated.

Third, subsidiaries with a mandate often exhibit highly specialized, hard-toimitate - and thus, rare - competencies (Birkinshaw et al. 1998; Cantwell and Mudambi 2005). Such rare competencies increase the subsidiary's power inside the MNC network (Bouquet and Birkinshaw 2008). This increased power should provide the focal subsidiary with an improved bargaining position that enables it to directly appropriate a higher level of the rents that are available within the intra-MNC network (Mudambi and Navarra 2004).

Therefore, by giving the focal subsidiary a mandate, the parent firm should be able to positively influence the subsidiary's performance and thus its global integration. Thus,

Hypothesis 2: Subsidiary performance will be positively associated with the possession of a subsidiary mandate received from the parent firm. 
Hypotheses 3a and 3b: Association between Autonomy and Subsidiary Performance

We model subsidiary autonomy by two distinct categories: strategic and operational autonomy, following relevant literature that recommends this differentiation (Bartlett and Ghoshal 1989; Birkinshaw 1996; Birkinshaw and Morrison 1995; Nobel and Birkinshaw 1998; Vereecke et al. 2006). We believe this differentiation is important since "autonomy is a rather fuzzy concept unless the distinction is drawn between strategic autonomy and operational autonomy” (Glaister et al. 2003, p. 320). Strategic autonomy is defined as the subsidiary's ability to set its own agenda, whereas operational autonomy is defined as the ability to manage designated activities in a way determined by the subsidiary itself (Bailyn 1985; Perlow 1998).

We argue that strategic autonomy will have negative implications for the subsidiary’s performance and its integration in the MNC. Put differently, autonomy can imply a lack of, endanger or actually damage integration of the subsidiary into the intra-firm network (Birkinshaw et al. 1998). This effect is likely to be stronger the more the subsidiary has the power to determine its own agenda, i.e. the more strategic autonomy it has. If the MNC wants to ensure the seamless integration of a specific subsidiary's capabilities into the intra-MNC network, it is highly likely to endow that subsidiary with less autonomy to determine its own agenda, i.e. to reduce its strategic autonomy (Frost et al. 2002). For example, Ambos and Schlegelmilch (2007) found that the "international creator" type of subsidiary, i.e. one with distinct proprietary competence which the MNC wishes to spread throughout the global organization, had the highest degree of centralization and the least freedom to determine its own agenda. Thus, the more tightly integrated the subsidiary becomes in the corporate 
system, the more decisions of a truly strategic nature are taken out of the subsidiary's hand and held at a corporate level (Birkinshaw et al. 2005, p. 235, emphasis added).

The integration of highly autonomous subsidiaries is likely to be lower due to a lack of coordination between the parent firm and the subsidiary which could lead to the subsidiary's isolation from the rest of the organization; with a high degree of strategic autonomy, “the subsidiary can drop ‘out of the loop’ and weaken its intrafirm position” (Cantwell and Mudambi 2005, p. 1114). With increasing isolation from the rest of the MNC, it becomes less likely that the subsidiary's capabilities and resources are recognized as being beneficial to the overall MNC network (Birkinshaw et al. 1998) so that the parent company may be less inclined to foster the further development of these capabilities and resources by additional investments (Frost et al. 2002).

Moreover, the capabilities and resources a subsidiary develops and uses in isolation are potentially less compatible with the capability and resource stocks controlled by other units within the MNC. This may limit the subsidiary's ability to benefit from the capabilities and resources available in the MNC network (Kogut and Zander 1992, 2003). Further, the subsidiary should be interested in promoting such compatibility, since recombinations of capabilities and resources from different locations are especially hard to imitate (McEvily and Chakravarthy 2002). Therefore, if the subsidiary can recombine its own resources and capabilities with those of other organizational units, it may well achieve an improved inimitability of its resource base. This, in turn, may improve its financial performance in the long run since the uniqueness of a resource increases with its inimitability (Barney 1991). Finally, when other units are less able to make use of the capabilities and resources developed by the focal subsidiary, the role of this subsidiary within the MNC is weakened (Forsgren 
and Pedersen 2000; Forsgren et al. 2000). The financial performance of a subsidiary with high strategic autonomy may therefore be hampered by a reduced ability to influence strategic decisions of the MNC and to appropriate firm-internal rents (Mudambi and Navarra 2004). Therefore, the less a subsidiary can alter its resource base and capabilities independently, the lower should the probability be that such changes will lead to incompatibility. Thus,

Hypothesis 3a: Subsidiary performance will be negatively associated with the subsidiary's level of strategic autonomy.

The degree of operational autonomy a subsidiary possesses designates the range and extent of preset tasks it may address autonomously. One of the areas in which an operationally autonomous subsidiary might make its own decisions is the cooperation with external firms and organizations which is largely an operational, rather than a strategic issue (Nobel and Birkinshaw 1998). Being allowed to collaborate with external partners of its own choice, the subsidiary is probably better able to form favorable linkages with parties in its local environment (Andersson and Forsgren 2000; Birkinshaw et al. 1998). Thus, it can learn more from the local system of innovation and better use and recognize local resources and competencies (Andersson et al. 2002; Pearce 1999; Rugman and Verbeke 2001). Indeed, knowledge about external opportunities can be considered a resource itself (Cyert et al. 1993). Thus, the higher its operational autonomy, the more the subsidiary should be able to learn from external sources and thus to improve its resource base. With its stronger knowledge about external opportunities, a subsidiary with high operational autonomy should also be more responsive to these opportunities which has been found to improve performance (Zahra and Covin 1995). 
Additionally, a subsidiary that is granted only little operational autonomy by its parent firm is likely bound to provide its employees with less operational autonomy than it could if it had received more operational autonomy itself. Yet, operational autonomy gives employees the opportunity to "approach problems in ways that make the most of their expertise and creative-thinking skills" (Amabile 1997, p. 82) and thus fosters their intrinsic motivation, creativity, and finally organizational innovation (Amabile 1997; Glynn 1996). Therefore, subsidiaries are likely to create both new knowledge and competencies due to their operational freedom (Ambos and Schlegelmilch 2007, p. 476, emphasis added). Moreover, this knowledge and these competencies should be relevant to the rest of the firm, since the tight control the parent firm is able to exert on the subsidiary's agenda will likely avoid duplication and irrelevance of any knowledge the subsidiary creates.

Finally, knowledge assets created by the interaction of the subsidiary with its local environment may be hard to imitate for other units within the MNC network. Thus, such knowledge assets can be very attractive to and create a lot of value for these other units. The expected demand for such rare assets may therefore provide the focal subsidiary with a stronger bargaining position within the MNC, allowing it to appropriate more firm-internal rents (Mudambi and Navarra 2004). Therefore, Hypothesis 3b: Subsidiary performance will be positively associated with the subsidiary's level of operational autonomy.

\section{Data and Methods}

Population and Sampling Frame 
Our sample consisted of subsidiaries with a main responsibility for research and development (R\&D). We used the database ThomsonOne to identify Swiss and German firms irrespective of their industry affiliation. We focused on Swiss and German firms because they are characterized by a high degree of $R \& D$ internationalization (Serapio and Dalton 1999). The search yielded a list of 1,254 firms (983 German, 271 Swiss).

We only retained those firms that were MNCs and which had deliberately set up an international R\&D structure (Bartlett and Ghoshal 1989). We checked these criteria by reading the annual report of every firm and by making additional confirmatory phone calls. This process resulted in the exclusion of 750 firms from the sampling frame. The remaining 504 firms accounted for an average of $68 \%$ of all sales in their respective industry. We then contacted the top management of these remaining firms, explained our research topic and asked for participation in the study. 159 firms (104 German, 55 Swiss) chose to cooperate. Correspondence with corporate-level senior R\&D managers of these firms led to the identification of 923 foreign subsidiaries. These constituted the population from which we drew our random sample.

Item Development

Our measurement approach is largely based on the collection of psychometric survey data from individual informants. The use of such shared unit-level constructs (Klein and Kozlowski 2000) is of course an approximation as different individuals have different perceptions about subsidiary characteristics, and thus the projection of individual-level cognition to the organizational level should be considered a heuristic 
(Schneider and Angelmar 1993). However, the interviews during the item revision phase suggested that a subsidiary’s general or top $R \& D$ manager would likely be in a position to make sound assessments. We therefore think our approach is acceptable as it can be presumed that individual top-level employees are most familiar with their subsidiary's characteristics and its relationships with other units in the firm.

For item generation, we conducted a careful review of the relevant literature and related scales. With the exception of the variable "inter-subsidiary knowledge asset transfer”, all measures were adopted from existing scales. As to the best of our knowledge no scale to measure "inter-subsidiary knowledge asset transfer" is available, we employed a rigorous item creation and validation process for this scale, following recommendations in the measurement literature (Churchill 1979; Schriesheim et al., 1993). This process started with a preliminary item list that we produced based on the literature review and consisted of iterative rounds of discussions with international academics and $R \& D$ managers from four MNCs to ensure content, face, and external validity of our emerging construct. To incorporate their feedback, we made substantive changes to the latest list if necessary, and discussed the revised list again with professors and managers until both groups came to the conclusion that no further clarifications and amendments would be necessary. This process enabled us to produce a carefully tested questionnaire instrument. 
Measurement

All constructs considered in this investigation refer to the subsidiary as the unit of analysis. Accordingly, all variables were specified on the subsidiary level. The items and scales are reproduced in appendix A. All scales were constructed by adding up individual item scores and dividing the sum by the number of items in the scale (Dess and Davis 1984; Trevor and Nyberg 2008).

Dependent Variable

Subsidiary performance was measured by a three item scale that we adapted from Birkinshaw and Morrison (1995). We used seven-point items anchored at "we perform much worse than the parent firm" (1) and "we perform much better than the parent firm” (7). Given the above scale construction method, the scale is conditioned on values between 1 and 7, which is why we prefer Tobit models for analysis (Cronbach’s alpha $=0.8990)$.

Independent Variables

Knowledge asset transfer was measured by a self-developed six item scale anchored at "not at all" (1) and "to a great extent" (7). It measures the extent to which knowledge assets developed by the focal subsidiary were of use in sister units (alpha $=0.9378)$.

Operational autonomy and strategic autonomy were measured by scales that we adapted from Nobel and Birkinshaw's (1998) “centralization” scale”; the items 
were anchored at "headquarters decide” (1) and "subsidiary decides” (7). "Strategic autonomy" is defined as the subsidiary's ability to set its own agenda, whereas “operational autonomy” is defined as the ability to deal with designated day-to-day issues autonomously (Bailyn 1985; Perlow 1998) (alpha $=0.6892$ for strategic and 0.6862 for operational autonomy).

Subsidiary mandate status was measured by a dichotomous indicator originally developed by Birkinshaw et al. (1998). We asked the respondents "Does your subsidiary undertake any $R \& D$ activity on behalf of the corporation as a whole?”. This indicator was coded “1” if the subsidiary has received a mandate from the parent firm, and “0” otherwise.

\section{Control Variables}

Tacitness of subsidiary's knowledge. By combining items from Zander and Kogut's (1995) “teachability” and "codifiability” scales, we created the scale for our control variable "tacitness". It measures how easily the subsidiary's knowledge can be described and learned; the items were anchored at "strongly disagree" (1) and “strongly agree” (7) (alpha $=0.8312)$.

Observability of subsidiary's knowledge. We control for observability by including the three-item scale of Birkinshaw et al. (2002). It measures how well the subsidiary’s knowledge can be learned by observation; the items were again anchored at "strongly disagree” (1) and "strongly agree” (7) (alpha = 0.7768).

Demographic controls. We control for subsidiary $R \& D$ intensity by its $R \& D$ expenses relative to its budget, for subsidiary size by the logged number of its employees, for subsidiary age by subtracting the year in which the subsidiary started 
operations for the parent firm from 2009, for subsidiary location by individual country dummies and for subsidiary industry by individual industry dummies on the two-digit level using the NACE classification.

Questionnaire, Data Collection Procedure and Post-Hoc Tests

We produced a fully standardized questionnaire by following validated academic procedures of questionnaire design (Dillman 2000). For data collection, each firm was emailed a copy of the questionnaire together with a cover letter that explained the aims of the study, guaranteed complete confidentiality, and offered the study results as an incentive to cooperate. By short telephone calls we announced the arrival of the questionnaire and asked the subsidiary's general manager or top R\&D manager (our key informants) for cooperation.

We emailed reminder letters to all managers that had not yet responded 14 and 30 days after the original questionnaire had been emailed. From the total of 923 subsidiaries, 290 responded, yielding a favorable response rate of 31.42\%. Three observations could not be used due to too much missing data, thus 287 complete observations remained for subsequent analysis. Missing data were few and completely at random.

We then carried out several post-hoc analyses and validation surveys to assure the representativeness of respondent data and to validate responses received from informants. No significant response bias by response vs. non-response, response time, and subsidiary demographic characteristics were detected.

Further, to minimize common method variance, we validated data collection by re-collecting data on the dependent variable "subsidiary performance" from the 
respective parent firm and by re-collecting the complete questionnaire data from a second manager in the subsidiary six weeks after initial data collection using randomly drawn subsamples. High inter-rater reliability between the original and the confirmation data alleviated common method bias concerns (Nunnally and Bernstein 1994). Further, there was no evidence of a large number of subsidiaries responding from a single MNC, so that our sample is unlikely to be biased by possible cluster effects.

Assessment of Reliability and Validity of Measures

We relied on diverse approaches to test the reliability and validity of both our items and our scales. All applied methods consistently suggest high levels of reliability and validity. $^{2}$ To test the reliability of our items, we calculated item-test, item-rest, and average inter-item correlations. On the scale level, we calculated Cronbach’s alpha for each scale (cf. Nunnally and Bernstein 1994).

To examine the convergent and discriminant validity of our measures, we relied on psychometric methods. Convergent validity of our items was established by calculating overlap-corrected ${ }^{3}$ correlations between an item and the scale it pertains to (cf. Nunnally and Bernstein 1994) and convergent validity of our scales by applying principal component factor analysis with oblique rotation. ${ }^{4}$ Ultimately, 23 items were retained which formed six scales. ${ }^{5}$ Table 1 reports loadings, cross-loadings, and communalities for these items. The scales capture the subsidiary's performance (Cronbach's alpha $=0.8990)$, its operational autonomy $($ alpha $=0.6862)$, its strategic autonomy (alpha $=0.6892$ ), its knowledge asset transfer (alpha $=0.9378$ ), the 
tacitness of its knowledge (alpha $=0.8312$ ) as well as the observability of its knowledge (alpha $=0.7768)$.

$<<$ Insert Table 1 about here $>>$

Together, these six factors explain $70.09 \%$ of the variance. Direct factor loadings were high (all above 0.60 ), while no cross-loading exceeded 0.30 , indicating a high degree of convergent validity (Hair et al. 1998). We used Harman’s one-factor test to assess potential common method variance induced by our use of single informants to measure corporate characteristics. The fact that six factors emerged and that the first factor only explained $20.50 \%$ of the variance makes it unlikely that common method variance is a major concern (Podsakoff and Organ 1986).

We then examined item discriminant validity by using a multitrait and multiitem correlation matrix approach in which the correlation of each item with each scale is examined (Ware and Gandek 1998). We further calculated average variance extracted and compared its square root to the correlation coefficients among the scales (Fornell and Larcker 1981; Staples et al. 1999). Both analyses suggested a high level of discriminant validity.

\section{Results}

Descriptive Statistics and Results of Hypothesis Testing

Table 2 provides descriptive statistics and correlations for all variables. Since the dependent variable is conditioned on values between 1 and 7, we fit Tobit models to our data. All estimates use robust (Huber-White) standard errors to correct for potential heteroscedasticity. All models were constructed incrementally by first 
entering only the controls in a baseline model and then adding the covariates of each hypothesis step by step. We compared the respective model fits by calculating Akaike information criteria (AIC); this procedure suggested that the full model which includes all independent variables and controls fits the data best. Since all industry and country dummies, respectively, are perfectly collinear, the machinery industry and Germany serve as the respective baseline categories in all models. Table 3 shows estimation results for the different models.

\section{$<<$ Insert Tables 2 and 3 about here $>>$}

For all hypotheses but one, the found signs match the predicted signs. Three of the four hypotheses are supported at $\mathrm{p}<0.05$ : H1 which posited a positive relationship between knowledge asset transfer and the subsidiary's performance, $\mathrm{H} 2$ which predicted a positive relationship between its mandate status and its performance, and H3b which posited a positive relationship between the subsidiary's operational autonomy and its performance. H3a which asserted a negative relationship between the subsidiary's strategic autonomy and its performance fails to gain support. Additionally, we find some of the control variables are significant: Subsidiaries located in Switzerland, in Non-Chinese Asia, and in "other locations" tend to achieve a significantly higher performance (all at $\mathrm{p}<0.05$ ) than subsidiaries located in Germany (our reference category).

Sensitivity tests and alternative specifications

We performed additional analyses to ensure the validity of these results. First, robust OLS regression models ${ }^{6}$, standardized normal probability plots, Shapiro-Wilk and Kolmogorov-Smirnov tests all indicated that the Tobit model assumptions were met 
and the estimated coefficients and standard errors were stable. To assess whether multicollinearity of measures was a problem, we computed variance inflation factor (VIF) indices. Both the maximum (2.16) and the mean VIF (1.54) are well below the threshold of 10, alleviating multicollinearity concerns (Chatterjee et al. 2000). While the magnitude of coefficients reflected the differences of OLS vs. Tobit model metrics, the patterns of significance across all hypothesized coefficients as well as their signs remained stable

Second, since our measurement approach is largely based on the collection of psychometric survey data from individual informants, we also applied structural equation modeling (SEM) to control for latent variable effects. With the exception of the country dummies, all independent and control variables of our full regression model were entered as exogenous variables and the dependent variable as the endogenous variable into the structural equation model. ${ }^{7}$ Covariances between the exogenous variables were modeled if the respective exogenous variables could be theoretically expected to covary and if the corresponding modification index was above 10.0 (cf. Denison et al. 1996; Sabherwal et al. 2006), indicating that including this covariance substantially improves model fit.

Figure 1 depicts the structure of the model using maximum likelihood (ML) estimation and reports standardized factor loadings and path coefficients. The model fits the data adequately $\left(\chi^{2}=686.807\right.$ with 509 d.f., $\mathrm{p}<0.000$; GFI $=0.862$; AGFI $=$ 0.829; NFI $=0.812 ; \mathrm{NNFI}=0.932 ; \mathrm{CFI}=0.942 ; \mathrm{RMSEA}=0.039)($ e.g., Bollen 1989; Kline 2005). As it can be seen from Figure 1, this model, too, supports H1 ( $<<0.01$ ), H2 ( $<0.10)$, and H3b ( $<<0.05)$, whereas H3a fails to gain support. Thus, the Tobit model results are confirmed.

$$
<<\text { Insert Fig. } 1 \text { about here }>>
$$




\section{Discussion}

Our study articulated and tested a model of how the parent firm of an MNC can achieve global integration of subsidiaries by using managerial "tools" to manipulate the MNC's formal organizational architecture. We used subsidiary performance as an observable criterion to measure integration success. The empirical results confirm our theoretical arguments that the parent firm can actively improve a subsidiary's performance and hence its integration by encouraging inter-subsidiary knowledge asset transfer, assigning subsidiary mandates, and providing operational autonomy. These results have implications for the literature and for managers.

First, we extend previous research on how integration can be achieved. Our study is one of the first to provide an unusually detailed account of the links between managerial action by "tools” that manipulate organizational structure and successful integration. It helps close the frequently highlighted knowledge gap concerning the link between managerial action and integration (e.g., Ambos and Ambos 2009; Björkman et al. 2004; Bouquet and Birkinshaw 2008; Foss and Pedersen 2002; Foss and Pedersen 2004; Luo 2002; Persaud 2005; Wu et al. 2007). The mechanisms of managerial "tools" we study allow academics and managers to track how the theoretical benefits of global integration can actually be achieved. This knowledge is in high demand (e.g., Andersson et al. 2002; Ghoshal 1986; Ghoshal and Nohria 1989; Rosenzweig and Singh 1991; Yamin and Sinkovics 2009).

Given the tendency among many MNCs to re-centralize or completely localize activities, the problems with global integration seem overwhelming (Benito et al. 2003; Currie and Kerrin 2004; Doz et al. 2006; Fors 1997; Pearce 1990; Rugman 
2005). We could show that successful integration is possible when firms take appropriate actions to induce it, making a case that global integration is possible if appropriate “tools” are used.

By using subsidiary performance as a measure for successful integration, we also contribute to the investigation of antecedents of subsidiary performance on which empirically validated knowledge is very scarce (Monteiro et al. 2008). The finding that by encouraging knowledge asset transfers from the subsidiary to other organizational sub-units, the parent firm can actively promote subsidiary performance extends prior research that analyzes the effect of knowledge sharing on the performance of an individual unit (e.g., Monteiro et al. 2008; Tsai 2001). Whereas these previous observations of a positive association did not account for the extent to which the recipient has actually used the transferred knowledge, our results suggest that the positive association persists when the extent of knowledge use is considered. Moreover, this finding responds to the call that the actual outcomes of knowledgebased production, rather than the transfer of knowledge itself, should be studied (Ambos and Ambos 2009; Haas and Hansen 2005; Kotabe and Mudambi 2004; Yamin and Otto 2004). Further, our use of subsidiary performance as the dependent construct allows us to extend previous studies that have used knowledge-based perspectives to study global integration (e.g., Björkman et al. 2004; Foss and Pedersen 2002), corroborating theoretical predictions that multidimensional conceptualizations of global integration may be fruitfully employed in large-sample empirical testing (e.g., Persaud 2005; Yeniyurt et al. 2005).

We found no support for the hypothesized negative association between strategic autonomy and subsidiary performance. This could be due to the fact that a subsidiary empowered to decide about strategic issues independently is unlikely to use 
this freedom to detach itself from the MNC's global organization. Rather, such a subsidiary is likely to behave such that it can still reap the benefits of intra-firm collaboration while maintaining its relatively high degree of independence (cf. Cantwell and Mudambi 2005; Persaud 2005).

Moreover, our results suggest that strategic and operational autonomy do not have the same effect on successful global integration. We believe that the distinction between strategic and operational autonomy can at least partly explain why the overall findings regarding autonomy are unclear (see Birkinshaw and Morrison 1995; Nobel and Birkinshaw 1998; Vereecke et al. 2006). Thus, our findings answer the repeated call for a better understanding of the autonomy construct (Ambos and Schlegelmilch 2007; Glaister et al. 2003; Young and Tavares 2004). Our study is among the first to explicitly formulate separate hypotheses for strategic and operational autonomy. We believe that our findings and theoretical arguments open up promising paths for future research that can build on our results to deepen the theoretical understanding and nuances of subsidiary autonomy.

By highlighting the association between integration and subsidiary performance, our study complements the literature that stresses the benefits of integration from the parent company's or the overall MNC's view (e.g., Bartlett and Ghoshal 1989; Cavusgil et al. 2004; Townsend et al. 2004; Yeniyurt et al. 2005; Zou and Cavusgil 2002). There are basically two ways for a subsidiary to attain superior financial performance - first, by being successful on the external market, and second, by using its bargaining power to appropriate more internal rents (Mudambi and Navarra 2004). Our hypotheses are built on both arguments, suggesting that the parent firm's endeavors to integrate the subsidiary more tightly into the MNC's global network allow the subsidiary to improve both its supply for the external market and its 
firm-internal bargaining position. We acknowledge the argument that internal rentseeking by subsidiaries may be inefficient from a parent firm perspective (Mudambi and Navarra 2004, p. 386), implying that superior subsidiary performance does not necessarily entail superior corporate performance. ${ }^{8}$ Yet, given that the above literature linking integration and overall firm performance consistently suggests that global integration is profitable from the overall firm's perspective, it seems that the parent company and its subsidiaries have a common interest in a successful global integration of the MNC. This bears an important implication for those future studies that aim to explain why a considerable share of MNCs apparently experiences substantial problems in realizing the prospective benefits of becoming an integrated company: we show that these problems are unlikely to be rooted in categorical subsidiary resistance against the parent's strategy.

Our findings also have a number of managerial implications. First, parent firm managers can benefit from our explanations of how managerial "tools” are associated with subsidiary performance and integration since they provide managers with relatively straightforward suggestions of how to deploy these "tools" (Foss and Pedersen 2002). Further, they can benefit from our finding that tight integration into the MNC's global network can be profitable from the subsidiary's point of view. Thus, parent firm managers may review and adjust monitoring devices and expenditure used in headquarter-subsidiary relationships since the subsidiaries' selfinterest in good performance should motivate them to attend to the parent firm's goals (cf. Aulakh et al. 1996; Eisenhardt 1989; Osterloh and Frey 2000). At the same time, parent firm managers might consider instruments to counter rent-seeking behavior of subsidiary managers that may thwart this motivation, e.g. by establishing intersubsidiary teams to build emotional loyalty (Mudambi and Navarra, 2004). 
Our study also opens up some paths for future research. First, a more intensive examination of strategic vs. operational autonomy seems desirable. Further, future research could also extend our study by studying the extent to which the positive association between integration and subsidiary performance can be traced to internal rent appropriation as opposed to external market position. Separating these influences conceptually and empirically would provide an excellent robustness test for our argument that the parent firm and its subsidiaries should have a common interest in achieving successful global integration. It would be particularly instructive to examine the relationship between global integration and strong subsidiary performance after controlling for internal rent-seeking.

We focused on a carefully selected subset of managerial "tools" by which the formal organizational structure can be manipulated. Future research could complement our approach by studying "tools" that can manipulate the informal organizational structure and the interactions (if any) between these two types of “tools”. Further, since our cross-sectional empirical approach only allows us to infer association, not causality, more processual approaches that focus on the microprocesses of integration over time seem desirable. Further, knowledge flows and performance may be self-reinforcing mechanisms since consistent above-average performance may provide a subsidiary with slack resources that can further facilitate knowledge transfers (Monteiro et al. 2008, p. 103). Thus, future research could use endogeneity or simultaneous-equation models to study such recursive paths. Finally, we collected shared-level constructs from individual respondents to operationalize our constructs. While the techniques we used to assert the reliability and validity of our measures suggested the absence of significant subjective bias, future research may complement our work with archival measures to triangulate data sources. 


\section{Acknowledgements}

We thank the editors of the Focused Issue and two anonymous reviewers for their valuable suggestions that helped to improve this article. We also thank Glenn Hoetker, Ram Mudambi, Bodo B. Schlegelmilch, and session participants at the 2007 AIB conference in Milan for providing feedback on the ideas this manuscript is built on. We finally thank Frank Faulbaum and Heiko Gebauer for their helpful comments on structural equation modeling.

\section{Endnotes}

${ }^{1}$ Nobel and Birkinshaw (1998, p. 495) found that their centralization scale resulted in two different factors which they termed "strategic issue centralization" and "operational issue centralization", respectively.

${ }^{2}$ The results of these calculations are not reported here due to limitation of space, they are available from the corresponding author.

${ }^{3}$ That is, the scale is calculated without the specific item in question to avoid inflating the correlation.

${ }^{4}$ We used oblique rotation because we expected the emerging factors to be theoretically related (Hair et al. 1998).

${ }^{5}$ Both the Bartlett test of sphericity ( $\chi^{2}=2935.726$ with 253 d.f., $p=0.000$ ) and the Kaiser-MeyerOlkin measure of sampling adequacy (MSA $=0.8016$, “meritorious") indicated the data matrix was eligible for factor analysis. A factor was retained prior to rotation if its eigenvalue was greater than unity (Kaiser-Guttman criterion).

${ }^{6}$ The results of the robust OLS analyses are available from the corresponding author upon request.

${ }^{7}$ While model fit is still acceptable when country dummies are included as well, we prefer to omit them since their inclusion does not significantly change the pattern in which the SEM supports our hypotheses.

${ }^{8}$ We are grateful to an anonymous reviewer for pointing our attention to this issue. 


\section{Appendix: Questionnaire Items}

The following list gives an overview over the items that were synthesized into the respective factor according to the results of the reported factor analysis. All items were measured on Likert scales ranging from 1 to 7.

Subsidiary Performance (Cronbach's alpha $=0.8990)$ :

Regarding the following criteria, how does your subsidiary perform compared to your parent company? " 1 ” means "we perform much worse than the parent company”, “4” means "our performance is equal to the parent firm", and "7" means "we perform much better than the parent firm”.

- PERFROI: Return on Investment

- PERFPROFIT: Profit

- PERFCF: Cash Flow

Inter-Subsidiary Knowledge Asset Transfer (alpha = 0.9378)

“1” means "not at all”, “7” "to a great extent”.

- KAT1: Our subsidiary has developed product technology that was also applied in other subsidiaries.

- KAT2: Our subsidiary has developed process technology that was also applied in other subsidiaries.

- KAT3: Our subsidiary has developed information and know-how that was also applied in other subsidiaries.

- KAT4: Technology developed by our subsidiary helped to save R\&D expenditure in other subsidiaries.

- KAT5: Our subsidiary created competencies that were useful in other subsidiaries.

- KAT6: By transferring technology developed by our subsidiary, we have created value in other subsidiaries.

Strategic Autonomy $($ alpha $=0.6892)$ 
Who makes the decisions regarding the following points? " 1 ” means "parent alone decides" and "7" means "subsidiary alone decides".

- STAUT1: Overall direction of the subsidiary’s activities

- STAUT2: Which new projects to pursue

- STAUT3: Product design

Operational Autonomy (alpha $=0.6862)$

Who makes the decisions regarding the following points? " 1 ” means "parent alone decides” and “7” means "subsidiary alone decides”.

- OPAUT1: Hiring and firing senior staff

- OPAUT2: Training programs for subsidiary staff

- OPAUT3: Salary level of subsidiary employees

- OPAUT4: Transfer of subsidiary staff between units

Tacitness of Knowledge (alpha $=0.8312)$

“1” means "strongly disagree”, “7” "strongly agree”.

- TAC1: The way our technology works can easily be described in manuals.

- TAC2: New staff can easily learn about our activities by talking to skilled employees.

- TAC3: Training new personnel is typically a quick and easy job for us.

- TAC4: New personnel with a university degree can learn fast about our technology.

Observability of Knowledge $($ alpha $=0.7768)$

“1” means “strongly disagree”, “7” “strongly agree”.

- OBS1: Competitors could learn about our technology by observing our employees.

- OBS2: Competitors could learn about our technology by taking a tour of our facilities.

- OBS3: Competitors could learn how to manufacture our products by examining our machines and equipment. 


\section{References}

Almeida, P., \& Phene, A. (2004). Subsidiaries and knowledge creation: The influence of the MNC and host country on innovation. Strategic Management Journal, 25(8/9), 847-864.

Amabile, T. M. (1997). How to kill creativity. Harvard Business Review, 75(5), 76-87.

Ambos, T. C., \& Ambos, B. (2009). The impact of distance on knowledge transfer effectiveness in multinational corporations. Journal of International Management, 15(1), 1-14.

Ambos, B., \& Schlegelmilch, B. B. (2007). Innovation and control in the multinational firm: A comparison of political and contingency approaches. Strategic Management Journal, 28(5), 473-486.

Amit, R., \& Schoemaker, P. (1993). Strategic assets and organizational rent. Strategic Management Journal, 14(1), 33-46.

Andersson, U., \& Forsgren, M. (2000). In search of centre of excellence: Network embeddedness and subsidiary roles. Management International Review, 40(4), 329-350.

Andersson, U., Forsgren, M., \& Holm, U. (2001). Subsidiary embeddedness and competence development in MNCs - A multi-level analysis. Organization Studies, 22(6), 1013-1034.

Andersson, U., Forsgren, M., \& Holm, U. (2002). The strategic impact of external networks: Subsidiary performance and competence development in the multinational corporation. Strategic Management Journal, 23(11), 979-996.

Asmussen, C. G., Pedersen, T., \& Dhanaraj, C. (2009). Host-country environment and subsidiary competence: Extending the diamond network model. Journal of International Business Studies, 40(1), 42-57.

Aulakh, P. S., Kotabe, M., \& Sahay, A. (1996). Trust and performance in cross-border marketing partnerships: A behavioral approach. Journal of International Business Studies, 27(5), 10051032.

Bailyn, L. (1985). Autonomy in the industrial R\&D lab. Human Resource Management, 24(2), 129146.

Barney, J. (1991). Firm resources and sustained competitive advantage. Journal of Management, 17(1), 99-120.

Bartlett, C. A., \& Ghoshal, S. (1989). Managing across borders: The transnational solution. Boston: Harvard Business School Press.

Benito, G., Grogaard, B., \& Narula, R. (2003). Environmental influences on MNE subsidiary roles: Economic integration and the Nordic countries. Journal of International Business Studies, 34(5), 443-456.

Birkinshaw, J. (1996). How multinational subsidiary mandates are gained and lost. Journal of International Business Studies, 27(3), 467-495.

Birkinshaw, J., \& Hood, N. (1997). An empirical study of development processes in foreign-owned subsidiaries in Canada and Scotland. Management International Review, 37(4), 339-364.

Birkinshaw, J., \& Hood, N. (1998). Multinational subsidiary evolution: Capability and charter change in foreign-owned subsidiary companies. Academy of Management Review, 23(4), 773-795.

Birkinshaw, J. M., Hood, N., \& Jonsson, S. (1998). Building firm-specific advantages in multi-national corporations: The role of subsidiary initiative. Strategic Management Journal, 19(3), 221-241.

Birkinshaw, J. , Hood, N., \& Young, S. (2005). Subsidiary entrepreneurship, internal and external competitive forces, and subsidiary performance. International Business Review, 14(2), 227-248.

Birkinshaw, J., \& Morrison, A. J. (1995). Configurations of strategy and structure in subsidiaries of multinational corporations. Journal of International Business Studies, 26(4), 729-753.

Birkinshaw, J., Nobel, R., Ridderstrale, J. (2002). Knowledge as a contingency variable: Do the characteristics of knowledge predict organization structure? Organization Science, 13(3), 274289.

Björkman, I., Barner-Rasmussen, W., \& Li, L. (2004). Managing knowledge transfers in MNCs: The impact of headquarters control mechanisms. Journal of International Business Studies, 35(5), 443-455.

Bollen, K. A. (1989). Structural equations with latent variables. New York: Wiley. 
Bouquet, C., \& Birkinshaw, J. (2008). Weight versus voice: How foreign subsidiaries gain attention from corporate headquarters. Academy of Management Journal, 51(3), 577-601.

Buckley, P. J., \& Carter, M. (1996). The economics of business process design: Motivation, information and coordination within the firm. International Journal of the Economics of Business, 3(1), 5-25.

Cantwell, J. A. (1989). Technological innovation and multinational corporations. Oxford: Basil Blackwell.

Cantwell, J., \& Mudambi, R. (2005). MNE competence-creating subsidiary mandates. Strategic Management Journal, 26(12), 1109-1128.

Cavusgil, S. T., Yeniyurt, S., \& Townsend, J. D. (2004). The framework of a global company: A conceptualization and preliminary validation. Industrial Marketing Management, 33(8), 711716.

Chatterjee, S., Hadi, A., \& Price, B. (2000). Regression analysis by example. New York: Wiley.

Churchill, G. A. (1979). A paradigm for developing better measures of marketing constructs. Journal of Marketing Research, 16(1), 64-73.

Crook, T. R., Ketchen, D. J. Jr., Combs, J. G., \& Todd, S. Y. (2008). Strategic resources and performance: A meta-analysis. Strategic Management Journal, 29(11), 1141-1154.

Currie, G., \& Kerrin, M. (2004). The limits of a technological fix to knowledge management. Management Learning, 35(1), 9-29.

Cyert, R. M., Kumar, P., \& Williams, J. R. (1993). Information, market imperfections and strategy. Strategic Management Journal, 14(Winter Special Issue), 47-58.

Davis, L. N., \& Meyer, K. E. (2004). Subsidiary research and development, and the local environment. International Business Review, 13(3), 359-382.

Delios, A., \& Beamish, P. W. (1999). Geographic scope, product diversification, and the corporate performance of Japanese firms. Strategic Management Journal, 20(8), 711-727.

Denison, D. R., Hart, S. L., \& Kahn, J. A. (1996). From chimneys to cross-functional teams: Developing and validating a diagnostic model. Academy of Management Journal, 39(4), 10051023.

Dess, G., \& Davis, P. (1984). Porter's generic strategies as determinants of strategic group membership and organizational performance. Academy of Management Journal, 27(3), 467-488.

Dierckx, I., \& Cool, K. (1989). Asset stock accumulation and sustainability of competitive advantage. Management Science, 35(12), 1504-1511.

Dillman, D. (2000) Mail and internet surveys: The tailored design method. New York: Wiley.

Doz, Y., \& Prahalad, C. K. (1984). Patterns of strategic control within multinational corporations. Journal of International Business Studies, 15(2), 55-72.

Doz, Y., Wilson, K., Veldhoen, S., Goldbrunner, T., \& Altman, G. (2006). Innovation: Is global the way forward? Fontainebleau: INSEAD.

Dunning, J. H. (1994). Multinational enterprises and the globalization of innovatory capacity. Research Policy, 23(1), 67-88.

Eisenhardt, K. M. (1989). Agency theory: An assessment and review. Academy of Management Review, 14(1), 57-74.

Ethiraj, S. K., \& Levinthal, D. (2004). Bounded rationality and the search for organizational architecture: An evolutionary perspective on the design of organizations and their evolvability. Administrative Science Quarterly, 49(3), 404-437.

Feinberg, S. E. (2000). Do world product mandates really matter? Journal of International Business Studies, 31(1), 155-167.

Fornell, C., \& Larcker, D. (1981). Evaluating Structural Equation Models with unobservable variances and measurement error. Journal of Marketing Research, 18(1), 39-50.

Fors, G. (1997). Utilization of R\&D results in the home and foreign plants of multinationals. Journal of Industrial Economics, 45(3), 341-358.

Forsgren, M., Johanson, J., \& Sharma, D. (2000). Development of MNC Centers of Excellence. In U. Holm \& T. Pedersen (Eds.), The emergence and impact of MNC Centers of Excellence (pp. 4567). London: Macmillan. 
Forsgren, M., \& Pedersen, T. (2000). Subsidiary influence and corporate learning: Centers of Excellence in Danish foreign-owned firms. In U. Holm \& T. Pedersen (Eds.), The emergence and impact of MNC Centers of Excellence (pp. 68-78). London: Macmillan.

Foss, N. J., \& Pedersen, T. (2002). Transferring knowledge in MNCs: The role of sources of subsidiary knowledge and organizational context. Journal of International Management, 8(1), 49-67.

Foss, N. J., \& Pedersen, T. (2004). Organizing knowledge processes in the multinational corporation: An introduction. Journal of International Business Studies, 35(5), 340-349.

Frost, T., Birkinshaw, J., \& Ensign, P. (2002). Centers of Excellence in multinational corporations. Strategic Management Journal, 23(11), 997-1018.

Gates, S. R., \& Egelhoff, W. G. (1986). Centralization in headquarters-subsidiary relationships. Journal of International Business Studies, 17(2), 71-92.

Ghoshal, S. (1986). The innovative multinational: A differentiated network of organizational roles and management processes. Doctoral dissertation, Boston: Graduate School of Business Administration, Harvard University.

Ghoshal, S., \& Nohria, N. (1989). Internal differentiation within multinational corporations. Strategic Management Journal, 10(4), 323-337.

Glaister, K. W., Husan, R., \& Buckley, P. J. (2003). Decision-making autonomy in UK international equity joint ventures. British Journal of Management, 14(4), 305-322.

Glynn, M. A. (1996). Innovative genius: A framework for relating individual and organizational intelligences to innovation. Academy of Management Review, 21(4), 1081-1111.

Gouldner, A. W. (1960). The norm of reciprocity: A preliminary statement. American Sociological Review, 25(2), 161-178.

Granstrand, O., Hakanson, L., \& Sjölander, S. (1992). Technology management and international business: Internationalization of $R \& D$ and technology. Chichester: Wiley.

Gulati, R., Puranam, P., \& Tushman, M. (2009). Strategy and the design of organizational architecture. Strategic Management Journal, 30(5), 575-576.

Gupta, A. K., \& Govindarajan, V. (2000). Knowledge flows within multinational corporations. Strategic Management Journal, 21(4), 473-496.

Haas, M. R., \& Hansen, M. T. (2005). When using knowledge can hurt performance: The value of organizational capabilities in a management consulting company. Strategic Management Journal, 26(1), 1-24.

Hair, J. F. Jr., Anderson, R. E., Tatham, R. L., \& Black, W. C. (1998). Multivariate data analysis. Upper Saddle River: Prentice-Hall.

Hakanson, L. (1995). Learning through acquisitions: Management and integration of foreign R\&D laboratories. International Studies of Management \& Organization, 25(1/2), 121-157.

Hakanson, L., \& Nobel, R. (2001). Organization characteristics and reverse technology transfer. Management International Review, 41(4), 395-421.

Hansen, M. T. (1999). The search-transfer problem: The role of weak ties in sharing knowledge across organization subunits. Administrative Science Quarterly, 44(1), 82-111.

Hite, G. L., Owers, J. E., \& Rogers, R. C. (1987). The market for interfirm asset sales [-] partial selloffs and total liquidations. Journal of Financial Economics, 18(2), 229-252.

Johnston, S., \& Menguc, B. (2007). Subsidiary size and the level of subsidiary autonomy in multinational corporations: a quadratic model investigation of Australian subsidiaries. Journal of International Business Studies, 38(5), 787-801.

Klein, K. J., \& Kozlowski, S. W. J. (2000). Multilevel theory, research, and methods in organizations. San Francisco: Jossey-Bass.

Kline, R. B. (2005). Principles and practice of structural equation modeling. New York: Guilford Press.

Kogut, B., \& Zander, U. (1992). Knowledge of the firm, combinative capabilities, and the replication of technology. Organization Science, 3(3), 383-397.

Kogut, B., \& Zander, U. (2003). Knowledge of the firm and the evolutionary theory of the multinational corporation. Journal of International Business Studies, 34(6), 516-529. 
Kotabe, M., \& Mudambi, R. (2004). From markets to partnerships and hierarchies to coalitions: Perspectives on the modern multinational corporation. Journal of International Management, 10(2), 147-150.

Luo, Y. (2002). Organizational dynamics and global integration [-] A perspective from subsidiary managers. Journal of International Management, 8(2), 189-215.

Luo, Y. (2005). Toward coopetition within a multinational enterprise: A perspective from foreign subsidiaries. Journal of World Business, 40(1), 71-90.

McEvily, S. K., \& Chakravarthy, B. (2002). The persistence of knowledge-based advantage: An empirical test for product performance and technological knowledge. Strategic Management Journal, 23(4), 285-305.

Melin, L. (1992). Internationalization as a strategy process. Strategic Management Journal, 13(Winter Special Issue), 99-118.

Monteiro, L. F., Arvidsson, N., \& Birkinshaw, J. (2008). Knowledge flows within multinational corporations: Explaining subsidiary isolation and its performance implications. Organization Science, 19(1), 90-107.

Mudambi, R. (2002). Knowledge management in multinational firms. Journal of International Management, 8(1), 1-9.

Mudambi, R., \& Navarra, P. (2004). Is knowledge power? Knowledge flows, subsidiary power and rent-seeking within MNCs. Journal of International Business Studies, 35(5), 385-406.

Nickerson, J. A., \& Zenger, T. R. (2002). Being efficiently fickle: A dynamic theory of organizational choice. Organization Science, 13(5), 547-566.

Nobel, R., \& Birkinshaw, J. (1998). Innovation in multinational corporations: Control and communication patterns in international R\&D operations. Strategic Management Journal, 19(5), 479-496.

Nohria, N., \& Ghoshal, S. (1994). Differentiated fit and shared values: Alternatives for managing headquarters-subsidiary relations. Strategic Management Journal, 15(6), 491-502.

Nunnally, J., \& Bernstein, I. (1994). Psychometric theory. New York: McGraw-Hill.

Osterloh, M., \& Frey, S. (2000). Motivation, knowledge transfer, and organizational forms. Organization Science, 11(5), 538-550.

Pearce, R. (1990). The internationalisation of research and development. London: Macmillan.

Pearce, R. D. (1999). The evolution of technology in multinational enterprises: The role of creative subsidiaries. International Business Review, 8(2), 125-148.

Perlow, L. A. (1998). Boundary control: The social ordering of work and family time in a high-tech corporation. Administrative Science Quarterly, 43(2), 328-357.

Persaud, A. (2005). Enhancing synergistic innovative capability in multinational corporations: An empirical investigation. Journal of Product Innovation Management, 22(5), 412-429.

Podsakoff, P. M., \& Organ, D. (1986). Self-reports in organizational research: Problems and prospects. Journal of Management, 12(4), 531-544.

Rosenzweig, P. M., \& Singh, J. V. (1991). Organizational environments and the multinational enterprise. Academy of Management Review, 16(2), 340-361.

Rugman, A. (2005). The regional multinationals. Cambridge: Cambridge University Press.

Rugman, A., \& Verbeke, A. (2001). Subsidiary-specific advantages in multinational enterprises. Strategic Management Journal, 22(3), 237-250.

Roth, K., \& Morrison, A. J. (1992). Implementing global strategy: Characteristics of global subsidiary mandates. Journal of International Business Studies, 23(4), 715-735.

Sabherwal, R., Jeyaraj, A., \& Chowa, C. (2006). Information system success: Individual and organizational determinants. Management Science, 52(12), 1849-1864.

Schneider, S. C., \& Angelmar, R. (1993). Cognition in organizational analysis: Who's minding the store? Organization Studies, 14(3), 347-374.

Schriesheim, C., Powers, K., Scandura, T., Gardiner, C., \& Lankau, M. (1993). Improving construct measurement in management research: Comments and a quantitative approach for assessing the theoretical content adequacy of paper-and-pencil survey-type instruments. Journal of Management, 19(2), 385-417. 
Serapio, M. G., \& Dalton, D. H. (1999). Globalization of industrial R\&D: An examination of foreign direct investments in R\&D in the United States. Research Policy, 28(2/3), 303-316.

Staples, D. S., Hulland, J., \& Higgins, C. (1999). A self-efficacy theory explanation for the management of remote workers in virtual organizations. Organization Science, 10(6), 758-776.

Szulanski, G. (1996). Exploring internal stickiness: Impediments to the transfer of best practice within the firm. Strategic Management Journal, 17(Winter Special Issue), 27-43.

Szulanski G. (2003). Sticky knowledge: Barriers to knowing in the firm. London: Sage.

Teece, D. J., Pisano, G., \& Shuen, A. (1997). Dynamic capabilities and strategic management. Strategic Management Journal, 18(7), 509-533.

Townsend, J. D., Yeniyurt, S., Deligonul, Z. S., \& Cavusgil, S. T. (2004). Exploring the marketing program antecedents of performance in a global company. Journal of International Marketing, 12(4), 1-24.

Trevor, C. O., \& Nyberg, A. J. (2008). Keeping your headcount when all about you are losing theirs: Downsizing, voluntary turnover rates, and the moderating role of HR practices. Academy of Management Journal, 51(2), 259-276.

Tsai, W. (2001). Knowledge transfer in intraorganizational networks: Effects of network position and absorptive capacity on business unit innovation and performance. Academy of Management Journal, 44(5), 996-1004.

Tsai, W. (2002). Social structure of "coopetition" within a multiunit organization: Coordination, competition, and intraorganizational knowledge sharing. Organization Science, 13(2), 179-190.

Vereecke, A., Van Dierdonck, R., \& De Meyer, A. (2006). A typology of plants in global manufacturing networks. Management Science, 52(11), 1737-1750.

Ware, J.E., \& Gandek, B. (1998). Methods for testing data quality, scaling assumptions, and reliability: The IQOLA project approach. Journal of Clinical Epidemiology, 51(11), 945-952.

Wernerfelt, B. (1984). A resource-based view of the firm. Strategic Management Journal, 5(2), 171180.

Wu, F., Sinkovics, R. R., Cavusgil, S. T., \& Roath, A. S. (2007). Overcoming export manufacturers' dilemma in international expansion. Journal of International Business Studies, 38(2), 283-302.

Yamin, M., \& Otto, J. (2004). Patterns of knowledge flows and MNE innovative performance. Journal of International Management, 10(2), 239-258.

Yamin, M., \& Sinkovics, R. R. (2009). Infrastructure or foreign direct investment? An examination of the implications of MNE strategy for economic development. Journal of World Business, 44(2), 144-157.

Yang, Q., Mudambi, R., \& Meyer, K. E. (2008). Conventional and reverse knowledge flows in multinational corporations. Journal of Management, 34(5), 882-902.

Yeniyurt, S., Cavusgil, S. T., \& Hult, G. T. M. (2005). A global market advantage framework: The role of global market knowledge competencies. International Business Review, 14(1), 1-19.

Young, S., \& Tavares, A. T. (2004). Centralization and autonomy: Back to the future. International Business Review, 13(2), 215-237.

Zahra, S. A., \& Covin, J. G. (1995). Contextual influences on the corporate entrepreneurshipperformance relationship: A longitudinal analysis. Journal of Business Venturing, 10(1), 43-58.

Zander, U., \& Kogut, B. (1995). Knowledge and the speed of the transfer and imitation of organizational capabilities: An empirical test. Organization Science, 6(1), 76-92.

Zou, S., \& Cavusgil, S. T. (2002). The GMS: A broad conceptualization of global marketing strategy and its effect on firm performance. Journal of Marketing, 66(4), 40-56. 
Table 1: Final Set of Oblimin-Rotated Factors

\begin{tabular}{|c|c|c|c|c|c|c|c|}
\hline \multirow[b]{2}{*}{ Item (paraphrased) ${ }^{a}$} & \multicolumn{6}{|c|}{ Loading on oblimin-rotated factor } & \multirow[b]{2}{*}{ Communality } \\
\hline & $\begin{array}{c}1 \\
\text { “Knowledge } \\
\text { asset } \\
\text { transfer" }\end{array}$ & $\begin{array}{c}2 \\
\text { “Tacitness } \\
\text { of } \\
\text { knowledge" }\end{array}$ & $\begin{array}{c}3 \\
\text { “Subsidiary } \\
\text { performance" }\end{array}$ & $\begin{array}{c}4 \\
\text { “Observability } \\
\text { of knowledge” }\end{array}$ & $\begin{array}{c}5 \\
\text { “Strategic } \\
\text { autonomy" }\end{array}$ & $\begin{array}{c}6 \\
\text { “Operational } \\
\text { autonomy” }\end{array}$ & \\
\hline $\begin{array}{l}\text { PERFROI: Return on } \\
\text { Investment }\end{array}$ & 0.1586 & 0.0058 & 0.8777 & 0.0610 & -0.0371 & 0.0897 & 0.8086 \\
\hline PERFPROFIT: Profit & 0.0592 & 0.0695 & 0.9229 & -0.0273 & 0.0338 & -0.0245 & 0.8625 \\
\hline PERFCF: Cashflow & 0.1331 & -0.0020 & 0.8966 & 0.0349 & 0.0681 & 0.0217 & 0.8279 \\
\hline KAT1: Product technology & 0.8859 & -0.0102 & 0.0095 & 0.0558 & -0.0038 & 0.0254 & 0.7888 \\
\hline KAT2: Process technology & 0.8519 & 0.0305 & 0.1094 & -0.0188 & 0.0284 & -0.0192 & 0.7402 \\
\hline KAT3: Information and know-how & 0.8958 & 0.0760 & 0.0693 & -0.0397 & 0.0016 & -0.0104 & 0.8147 \\
\hline KAT4: Saving R\&D expenditures & 0.8415 & -0.0420 & 0.0009 & 0.0735 & -0.0643 & 0.0667 & 0.7239 \\
\hline KAT5: Competencies useful & 0.8711 & 0.0542 & 0.0961 & -0.0480 & 0.0643 & -0.0423 & 0.7792 \\
\hline KAT6: Creating value & 0.9132 & -0.0200 & 0.0766 & 0.0444 & -0.0489 & -0.0252 & 0.8451 \\
\hline $\begin{array}{l}\text { STAUT1: Overall direction of } \\
\text { activities }\end{array}$ & -0.1144 & 0.0245 & 0.1198 & -0.1186 & 0.7711 & 0.1257 & 0.6526 \\
\hline STAUT2: New projects to pursue & -0.0018 & -0.0205 & 0.0026 & 0.0455 & 0.8996 & 0.0873 & 0.8195 \\
\hline STAUT3: Product design & 0.1296 & -0.0585 & -0.0286 & 0.2509 & 0.6615 & 0.0917 & 0.5300 \\
\hline $\begin{array}{l}\text { OPAUT1: Hiring and firing senior } \\
\text { staff }\end{array}$ & -0.0182 & -0.0757 & 0.1034 & -0.0536 & 0.1909 & 0.6776 & 0.5152 \\
\hline OPAUT2: Training programs & 0.0773 & -0.0136 & -0.0339 & 0.0240 & 0.0306 & 0.7729 & 0.6061 \\
\hline OPAUT3: Salary level & -0.1058 & -0.0166 & 0.0187 & -0.0628 & 0.0683 & 0.7032 & 0.5150 \\
\hline OPAUT4: Transfer of subsidiary staff & -0.0109 & 0.0923 & 0.1544 & -0.0845 & 0.2861 & 0.6173 & 0.5025 \\
\hline TAC1: Easily described in manuals & 0.0227 & 0.7766 & 0.0003 & 0.1087 & 0.0134 & -0.0429 & 0.6175 \\
\hline TAC2: Talking to staff & 0.0661 & 0.8629 & 0.0229 & 0.1174 & 0.0565 & -0.0009 & 0.7664 \\
\hline TAC3: Training easy and quick & -0.0083 & 0.8051 & 0.0074 & 0.1319 & -0.0877 & -0.0103 & 0.6735 \\
\hline TAC4: University graduates & 0.0250 & 0.7762 & 0.0791 & 0.1489 & -0.0355 & 0.0277 & 0.6335 \\
\hline OBS1: Observing employees & 0.0402 & 0.2987 & 0.0520 & 0.7282 & -0.0054 & -0.0315 & 0.6249 \\
\hline OBS2: Tour of facilities & 0.0213 & 0.1928 & 0.0674 & 0.8435 & 0.0765 & -0.0200 & 0.7599 \\
\hline OBS3: Examining machines & 0.0247 & 0.0918 & -0.0266 & 0.8376 & -0.0057 & -0.0406 & 0.7131 \\
\hline Eigenvalue & 4.94 & 3.31 & 2.81 & 2.13 & 1.64 & 1.29 & \\
\hline Proportion of variance explained & $20.50 \%$ & $12.04 \%$ & $10.97 \%$ & $9.23 \%$ & $8.71 \%$ & $8.64 \%$ & \\
\hline Cumulative variance explained & $20.50 \%$ & $32.54 \%$ & $43.52 \%$ & $52.74 \%$ & $61.45 \%$ & $70.09 \%$ & \\
\hline
\end{tabular}

Note to table 1:

a. See the appendix for a full account of each item's wording. 
Table 2: Descriptive Statistics and Correlations ${ }^{\mathrm{a}, \mathrm{b}}$

\begin{tabular}{|c|c|c|c|c|c|c|c|c|c|c|}
\hline Variable & 1 & 2 & 3 & 4 & 5 & 6 & 7 & 8 & 9 & 10 \\
\hline 1 Subsidiary Performance & 1.000 & & & & & & & & & \\
\hline 2 Knowledge asset transfer & 0.156 & 1.000 & & & & & & & & \\
\hline 3 Subsidiary mandate & 0.159 & 0.264 & 1.000 & & & & & & & \\
\hline 4 Strategic autonomy & 0.068 & 0.024 & -0.009 & 1.000 & & & & & & \\
\hline 5 Operational autonomy & 0.064 & -0.004 & -0.009 & 0.330 & 1.000 & & & & & \\
\hline 6 Tacitness of knowledge & 0.046 & 0.036 & 0.059 & -0.024 & -0.034 & 1.000 & & & & \\
\hline 7 Observability of knowledge & -0.013 & 0.019 & 0.005 & 0.074 & -0.146 & 0.325 & 1.000 & & & \\
\hline 8 R\&D intensity & 0.011 & 0.188 & 0.211 & -0.063 & 0.064 & -0.118 & -0.201 & 1.000 & & \\
\hline 9 Size $^{c}$ & 0.081 & 0.350 & 0.254 & 0.115 & 0.074 & -0.068 & 0.037 & -0.056 & 1.000 & \\
\hline 10 Age & 0.140 & 0.298 & 0.070 & -0.002 & -0.114 & 0.002 & 0.035 & -0.084 & 0.215 & 1.000 \\
\hline Mean & 4.204 & 4.148 & 0.602 & 4.364 & 4.924 & 3.793 & 3.338 & 13.781 & 5.553 & 20.300 \\
\hline Std. dev. & 1.221 & 1.749 & 0.490 & 1.240 & 1.091 & 1.256 & 1.324 & 25.729 & 1.811 & 21.741 \\
\hline Min & 1 & 1 & 0 & 1 & 1.75 & 1 & 1 & 0 & 0.693 & 0 \\
\hline Max & 7 & 7 & 1 & 7 & 7 & 7 & 7 & 100 & 10.933 & 161 \\
\hline
\end{tabular}

Notes to table 2:

a. Correlations were computed under inclusion of the country and industry dummies as well. However, for the sake of brevity and readability, they are not reported here. These extensive results are available from the corresponding author.

b. Spearman correlations used due to the non-normal distribution of most variables. Correlations above $|0.118|$ are significant at $\mathrm{p}<0.05$.

c. Logged variable 
Table 3: Robust Tobit Estimates for Dependent Variable Subsidiary Performance ${ }^{\mathrm{a}, \mathrm{b}}$

\begin{tabular}{|c|c|c|c|c|}
\hline & $\begin{array}{c}\text { Model } 1 \\
\text { (Baseline } \\
\text { model) }\end{array}$ & Model 2 & Model 3 & $\begin{array}{c}\text { Model } 4 \\
\text { (Full model) }\end{array}$ \\
\hline Knowledge asset transfer & & $0.144 * *(0.056)$ & $0.123 *(0.058)$ & $0.125 *(0.058)$ \\
\hline Subsidiary mandate & & & $0.316 *(0.158)$ & $0.307 *(0.158)$ \\
\hline Strategic autonomy & & & & 0.009 (0.069) \\
\hline Operational autonomy & & & & $0.180 *(0.076)$ \\
\hline Tacitness & $0.074(0.073)$ & $0.093(0.076)$ & $0.088(0.076)$ & $0.085(0.074)$ \\
\hline Observability & $-0.028(0.072)$ & $-0.035(0.074)$ & $-0.035(0.073)$ & $-0.022(0.072)$ \\
\hline $\mathrm{R} \& \mathrm{D}$ intensity & $-0.000(0.003)$ & $-0.002(0.003)$ & $-0.002(0.003)$ & $-0.004(0.003)$ \\
\hline Size & $0.080(0.044)$ & $0.029(0.047)$ & $0.013(0.045)$ & $0.007(0.045)$ \\
\hline Age & $0.003(0.003)$ & $0.001(0.003)$ & $0.002(0.003)$ & $0.003(0.003)$ \\
\hline Switzerland & $0.734 * *(0.283)$ & $0.681 *(0.279)$ & $0.687 * *(0.274)$ & $0.636 *(0.279)$ \\
\hline USA & $0.203(0.269)$ & $0.227(0.262)$ & $0.232(0.257)$ & $0.203(0.274)$ \\
\hline China & $-0.092(0.289)$ & $0.094(0.303)$ & $0.074(0.296)$ & $0.035(0.301)$ \\
\hline Italy & $0.426(0.521)$ & $0.325(0.526)$ & $0.353(0.531)$ & $0.376(0.516)$ \\
\hline France & $-0.081(0.417)$ & $-0.183(0.434)$ & $-0.162(0.416)$ & $-0.068(0.401)$ \\
\hline UK & $0.752 *(0.352)$ & $0.667 *(0.330)$ & $0.698 *(0.331)$ & $0.634(0.347)$ \\
\hline Other Western Europe & $0.068(0.244)$ & $0.044(0.248)$ & $0.049(0.240)$ & $-0.023(0.249)$ \\
\hline Eastern Europe & $0.060(0.351)$ & $0.196(0.381)$ & $0.210(0.373)$ & $0.217(0.396)$ \\
\hline Other America & $0.024(0.570)$ & $0.297(0.567)$ & $0.306(0.579)$ & $0.342(0.586)$ \\
\hline Other Asia & $0.841 *(0.343)$ & $0.900 * *(0.326)$ & $0.896 * *(0.326)$ & $0.783 *(0.335)$ \\
\hline Other locations & $0.407(0.335)$ & $0.570(0.346)$ & $0.605(0.314)$ & $0.682 *(0.326)$ \\
\hline Electronics & $-0.014(0.240)$ & $-0.071(0.248)$ & $-0.064(0.244)$ & $-0.019(0.244)$ \\
\hline Chemicals & $-0.011(0.269)$ & $-0.024(0.276)$ & $-0.034(0.270)$ & $0.037(0.273)$ \\
\hline Pharmaceuticals & $-0.303(0.343)$ & $-0.225(0.340)$ & $-0.262(0.328)$ & $-0.228(0.327)$ \\
\hline Basic metals & $0.942 *(0.413)$ & $1.125^{* *}(0.411)$ & $1.179 * *(0.405)$ & $1.219 * *(0.390)$ \\
\hline Automotive & $0.580 *(0.271)$ & $0.512(0.273)$ & $0.502(0.275)$ & $0.623 *(0.291)$ \\
\hline Other transport equip. & $-0.591(0.383)$ & $-0.528(0.381)$ & $-0.646(0.380)$ & $-0.613(0.395)$ \\
\hline Electrical equipment & $0.238(0.440)$ & $0.282(0.409)$ & $0.295(0.398)$ & $0.396(0.431)$ \\
\hline \multirow[t]{2}{*}{ Other industries } & $-0.338(0.236)$ & $-0.332(0.243)$ & $-0.316(0.240)$ & $-0.217(0.237)$ \\
\hline & $3.272 * * *$ & $2.959 * * *$ & $2.950 * * *$ & $1.984 * * *$ \\
\hline Constant & $(0.369)$ & $(0.387)$ & $(0.387)$ & $(0.559)$ \\
\hline Log-pseudolikelihood & -381.102 & -369.516 & -367.564 & -357.151 \\
\hline McFadden's Pseudo $\mathrm{R}^{2}$ & 0.046 & 0.057 & 0.062 & 0.069 \\
\hline F statistic (d. f.) & $\begin{array}{r}2.23 * * *(24 \\
223)\end{array}$ & $\begin{array}{r}2.63 * * *(25 \\
217)\end{array}$ & $\begin{array}{r}2.91 * * *(26 ; \\
216)\end{array}$ & $\begin{array}{r}2.80 * * *(28 ; \\
208)\end{array}$ \\
\hline AIC & 814.204 & 793.031 & 791.127 & 774.301 \\
\hline Number of observations & 247 & 242 & 242 & 236 \\
\hline
\end{tabular}

Note to table 3:

a. ${ }^{*} \mathrm{p}<0.05 ;{ }^{* *} \mathrm{p}<0.01 ;{ }^{* * *} \mathrm{p}<0.001$ (two-tailed test). Robust standard errors in parentheses.

b. Baseline categories are Germany for the country and Machinery for the industry dummies. 
Fig. 1: Structural Equation Model ${ }^{\mathrm{a}, \mathrm{b}, \mathrm{c}, \mathrm{d}, \mathrm{e}, \mathrm{f}}$

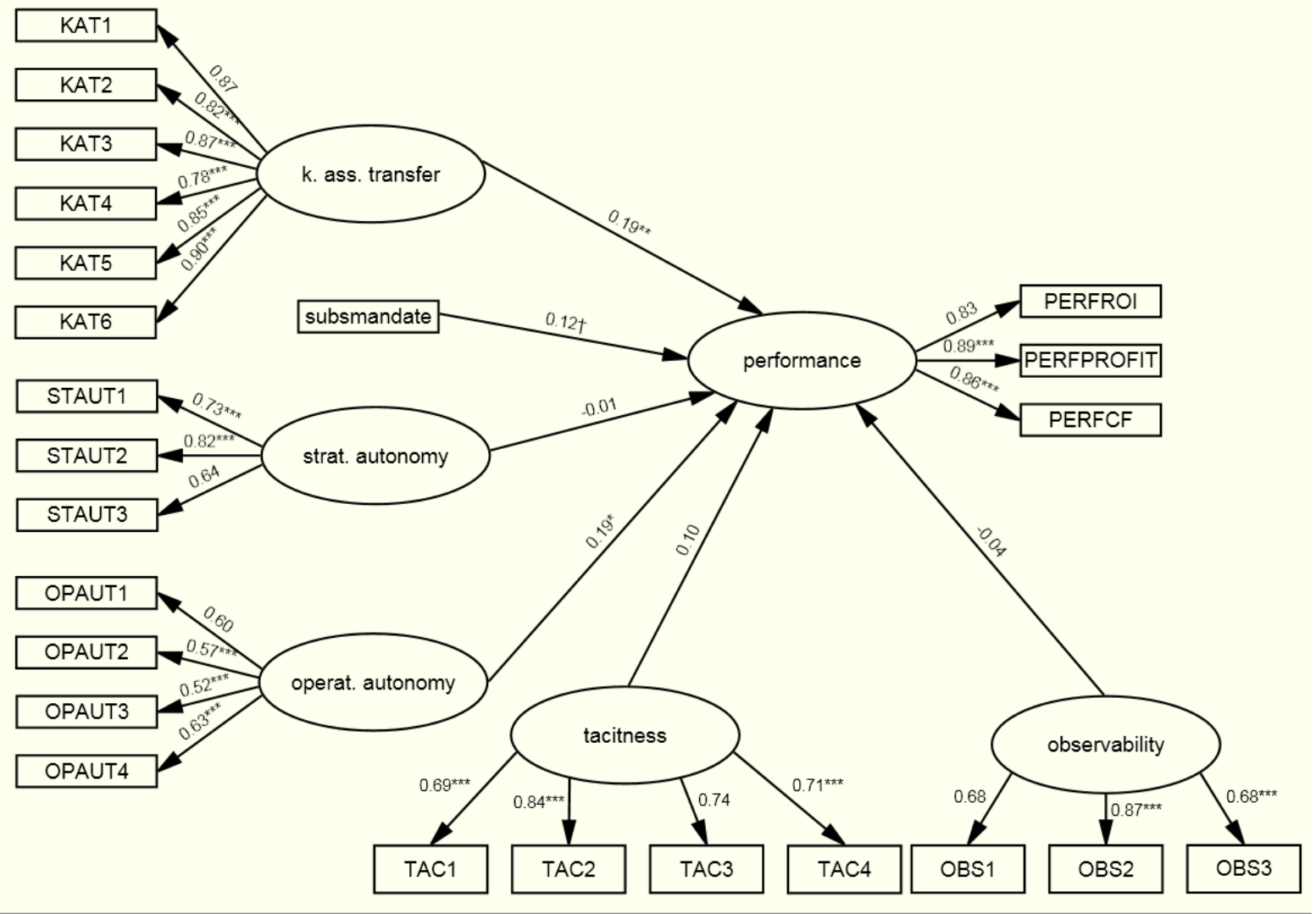

Notes to figure 1:

a. For reasons of readability, the figure shows only extracts of the model that was estimated. The estimation included further control variables, viz.: R\&D intensity, subsidiary size, subsidiary age, and industry dummies (as in the regression models, the machinery industry served as the reference category and was omitted from the analysis). Some covariances among exogenous variables were modeled, but are not reported here either. Error variables are also excluded from the presentation. Extensive results are available from the corresponding author upon request.

b. See the appendix for a full account of each item's wording.

c. Standardized estimates are reported.

d. Model fit: $\chi^{2}=686.807$ with 509 d.f., $\mathrm{p}=0.000$; GFI $=0.862$; $\mathrm{AGFI}=0.829$; $\mathrm{NFI}=$ 0.812 ; NNFI $=0.932 ; \mathrm{CFI}=0.942 ; \mathrm{RMSEA}=0.039$.

e. $\dagger \mathrm{p}<0.10 ;{ }^{*} \mathrm{p}<0.05 ;{ }^{* *} \mathrm{p}<0.01$; ${ }^{* * *} \mathrm{p}<0.001$ (two-tailed test).

f. In order to scale the factors, one indicator per factor was assigned a fixed unstandardized loading of 1.0. Therefore, one loading per factor cannot be tested for statistical significance (Kline 2005). 